\title{
Climate and surface mass balance of Mocho Glacier, Chilean Lake District, $40^{\circ} \mathrm{S}$
}

\author{
MARIUS SCHAEFER, ${ }^{1}$ JOSE LUIS RODRIGUEZ, ${ }^{2}$ MATTHIAS SCHEITER, ${ }^{3}$ \\ GINO CASASSA ${ }^{4,5}$ \\ ${ }^{1}$ Facultad de Ciencias, Instituto de Ciencias Físicas y Matemáticas, Universidad Austral de Chile, Valdivia, Chile \\ ${ }^{2}$ Enviros SpA, Temuco, Chile \\ ${ }^{3}$ Institut für Geophysik und Geoinformatik, Technische Universität Bergakademie Freiberg, Freiberg, Germany \\ ${ }^{4}$ Geoestudios, Las Vertientes, San José de Maipo, Chile \\ ${ }^{5}$ Universidad de Magallanes, Punta Arenas, Chile \\ Correspondence: Marius Schaefer<mschaefer@uach.cl>
}

\begin{abstract}
We present climate data, direct surface mass balance (SMB) observations and model results for Mocho Glacier in the Chilean Lake District. Mean annual temperature on a nunatak of Mocho Glacier at an elevation of $\sim 2000 \mathrm{~m}$ was $+2.6^{\circ} \mathrm{C}$ in 2006-15 and mean annual precipitation in Puerto Fuy (13 km from the glacier, at an elevation of $600 \mathrm{~m}$ ) was $4000 \mathrm{~mm}$ for the same period. High interannual variations in the SMB of Mocho Glacier were observed. A simple SMB model is able to reproduce the observed annual variations in SMB, but fails to predict the steep observed mass-balance gradient. The average of the measured annual glacier mass balances in the four hydrological years 2009/10-2012/13 was $-0.90 \mathrm{~m}$ w.e. $\mathrm{a}^{-1}$ and the average modelled annual glacier mass balance 2006/07-2014/15 was $-1.05 \mathrm{~m}$ w.e. $\mathrm{a}^{-1}$. The observed distributed ablation shows a clear altitudinal dependency, while accumulation is determined by patterns of snow drift as well. These patterns are only poorly represented in the model and have to be included in order to be able to reproduce a realistic SMB map of the glacier.
\end{abstract}

KEYWORDS: glaciological method, mountain glaciers, numerical modelling, surface mass balance

\section{INTRODUCTION}

Glaciers in the Patagonian Andes (Masiokas and others, 2009) are predominantly retreating and thinning during their observation period of the last decades, which coincides with trends of warming observed in the region (Rosenblüth and others, 1995). The changes in climate that are taking place at high elevations of the Andes and therefore also the surface mass balance (SMB) of its glaciers, however, are mostly unknown for the remote glaciers of the Patagonian Andes.

Retreat of the glaciers in the region has been reconstructed by analysing satellite images (Masiokas and others, 2009; López and others, 2010) and Little Ice Age trimlines (Davies and Glasser, 2012). Generally an accelerating retreat of glaciers has been observed, however the exact timing of the retreat has varied very much from glacier to glacier (Davies and Glasser, 2012). Glacier thinning in the region has been inferred by the comparison of DEM at different times (Rignot and others, 2003; Willis and others, 2012a, b), the so-called geodetic mass balance. The problem of inferring the glacier mass budget from the observed volume loss is the often unknown firn and snow density. Another drawback of this method is that locally, changes of the glacier surface can be caused by changes in glacier movement as well which cannot be distinguished from changes of the surface elevation due to SMB processes.

Inferences about the climate and the SMB of the Patagonian Icefields have been realized by modelling studies (Schaefer and others, 2013, 2015). In these studies, the modelled snow accumulation showed an increase, which has caused an increase in the SMB in the last 35 years. A decrease of the SMB of the Northern Patagonian Icefield (NPI) was modelled for the 21st century due to the projected warming, which will enhance ablation (Schaefer and others, 2013). Towards the end of the 21 st century a decrease of the accumulation of snow over NPI was projected due to a decrease of the fraction of solid precipitation (Schaefer and others, 2013).

On the Mocho Glacier $\left(40^{\circ} \mathrm{S}\right)$, in the Chilean Lake District, regular mass-balance measurements were initiated in 2003 (Rivera and others, 2005) by means of a stake network. The annual mass balance of Mocho Glacier, deduced from interpolations between the mass balance measured at the individual stakes, in the hydrological years 2003/04 and 2004/05 was -0.88 and $+0.18 \mathrm{~m}$ w.e. $\mathrm{a}^{-1}$, respectively (Rivera and others, 2005; Bown and others, 2007).

In this contribution we present a 9-year record of unpublished temperature data from an AWS on a nunatak of Mocho Glacier (Mocho1-AWS) at an elevation of $\sim 2000 \mathrm{~m}$. We present measured SMB data of four additional hydrological years on a stake network similar to the one of Rivera and others (2005). We study patterns of accumulation and ablation. Finally we try to reproduce the observed data with a semi-empirical mass-balance model, which uses a simplified energy balance to parametrize surface ablation (Oerlemans, 2001). This model has shown good performance for glaciers of similar size in the alps (Machguth and others, 2006a). We discuss the performance of the model and extend the SMB series to the 9-year period of data availability from Mocho1-AWS. 
In Section 2 we present details on the measurement site, the AWS, the set-up of the stake network and the SMB model. In Section 3 we present the results and in Section 4 we discuss and conclude.

\section{METHODS}

\subsection{The measurement site}

Mocho Glacier is a part of the ice cap covering the MochoChoshuenco Volcanic Complex, located in the Chilean Lake District at $39.93^{\circ} \mathrm{S}, 72.03^{\circ} \mathrm{W}$, and forms part of the active Southern Volcanic Zone (Rawson and others, 2015). The complex contains the Choshuenco peak in the north, an old edifice and the southern Mocho caldera, which makes it a double-peaked volcano. In the last decades, the glaciers of the ice cap covering the volcanic complex have strongly retreated, leading to an area loss of $40.5 \%$ from 1976 to 2003, from 29.4 to $16.9 \mathrm{~km}^{2}$ (Rivera and others, 2005).

As expected in the Southern Hemisphere, the most stable part of the ice cap, the Mocho Glacier, is located on the southeastern face of the complex (Fig. 1), covering an area of $5.1 \mathrm{~km}^{2}$ (Rivera and others, 2005), between the elevations of 1700 and $2400 \mathrm{~m}$. The glacier offers good conditions for mass-balance studies as it has comparatively easy access, logistic facilities and reliable meteorological stations nearby. Mass-balance measurements by means of a stake network have been carried out on Mocho Glacier since 2003.

\subsection{Climate data}

In 2006 an AWS was installed on a nunatak in the vicinity of the glacier (Mocho1-AWS in Fig. 1b) at an elevation of 1970 $\mathrm{m}$ a.s.I. . Wind speed and direction, incoming solar radiation, net radiation and air temperature at $2 \mathrm{~m}$ are measured at the AWS and mean values are stored every $15 \mathrm{~min}$. In this contribution we focus on the measurements of incoming solar radiation and temperature. In 2010 a further AWS was installed at an elevation of $1420 \mathrm{~m}$ a.s.l., below the glacier's tongue (Mocho2-AWS in Fig. 1b). Measured air temperature from the Mocho2-AWS was used to infer a mean temperature lapse rate, which was used to set up the distributed SMB model. Additionally precipitation data are presented, which were measured at an AWS maintained by the Chilean Water Directory (DGA) located in Puerto Fuy at the foot of the volcano at an elevation of $600 \mathrm{~m}$ a.s.l.(Fig. 1a), hereafter called PFuy-AWS.

\subsection{Surface mass balance}

\subsubsection{The glaciological method}

To infer the SMB of Mocho Glacier a slight modification of the classical glaciological method was adopted: ablation and accumulation were both measured at stakes which, due to the high mass turnover, were visited several times a year. The ablation stakes made of plastic (see Fig. 2a) were drilled into the snow or ice in the beginning of summer (November-January) by means of the Heucke steam drill (Heucke, 1999). By the end of the summer (end of April) aluminium tubes were installed as accumulation stakes (see Fig. 2b) to measure the strong accumulation associated with the frequent winter storms. These stakes were of 3-4 m length and were equipped with a connector with which another 3-4 m stake could be installed at places with high accumulation of snow. The snow density was measured during the campaigns at least at one stake by means of a snow pit of $1 \mathrm{~m}$ depth (Fig. 2c). To be able to infer the spatial variations the snow density was measured several times at all stakes by means of a Mount Rose snow sampler. By means of these measurements, coefficients were determined for all the stakes, which determined how the particular stake's snow density varied with respect to the stake where the snow pit was dug. The snow density values were used to convert measured differences in distance to mass in the case of accumulation as well as in the case of ablation of snow. In this latter case the density value inferred in the preceding campaign was used to realize this conversion.

\subsubsection{Correlation technique}

Due to the high mass turnover of the glaciers, several stakes were lost, which produced gaps in the stake data. These data gaps were filled by the statistical procedure described below:
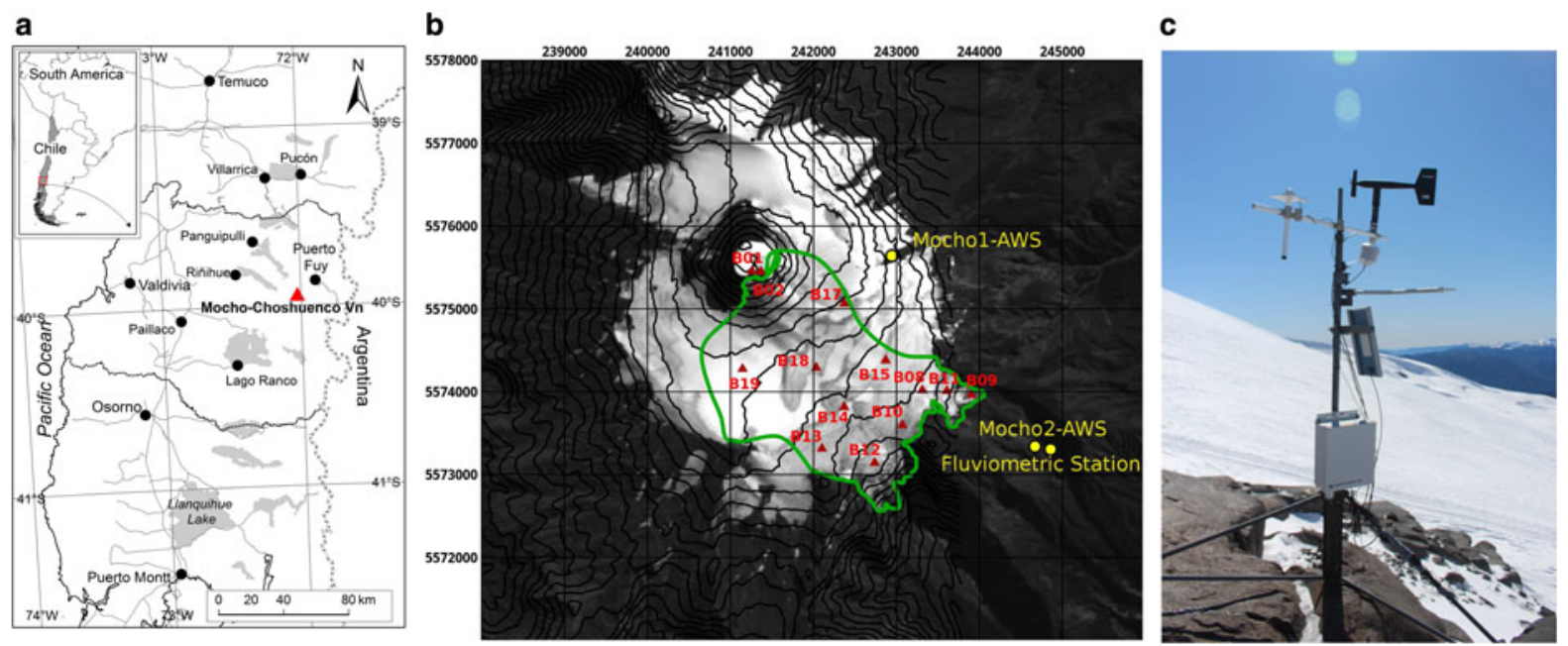

Fig. 1. (a) Location of the Mocho Glacier in the Lake District and in South America. (b) Definition of the Mocho Glacier and distribution of ablation and accumulation stakes on the Mocho Glacier; AWS are represented by the yellow dots, elevation contours every $50 \mathrm{~m}$; background image: Landsat scene from 11 April 2015. (c) AWS Mocho1. 

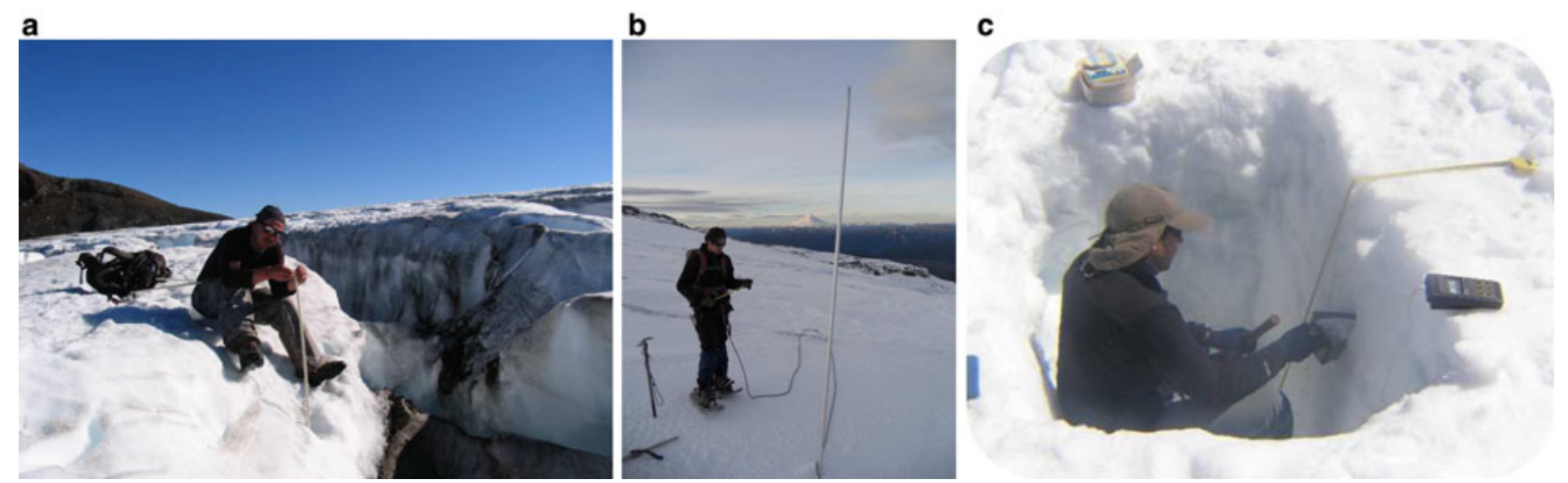

Fig. 2. (a) Ablation stake found at the end of the summer 2012 next to a crevasse; (b) accumulation stake with nearby volcano Lanín in the background; (c) measuring snow density with a standard wedge at the snow pit.

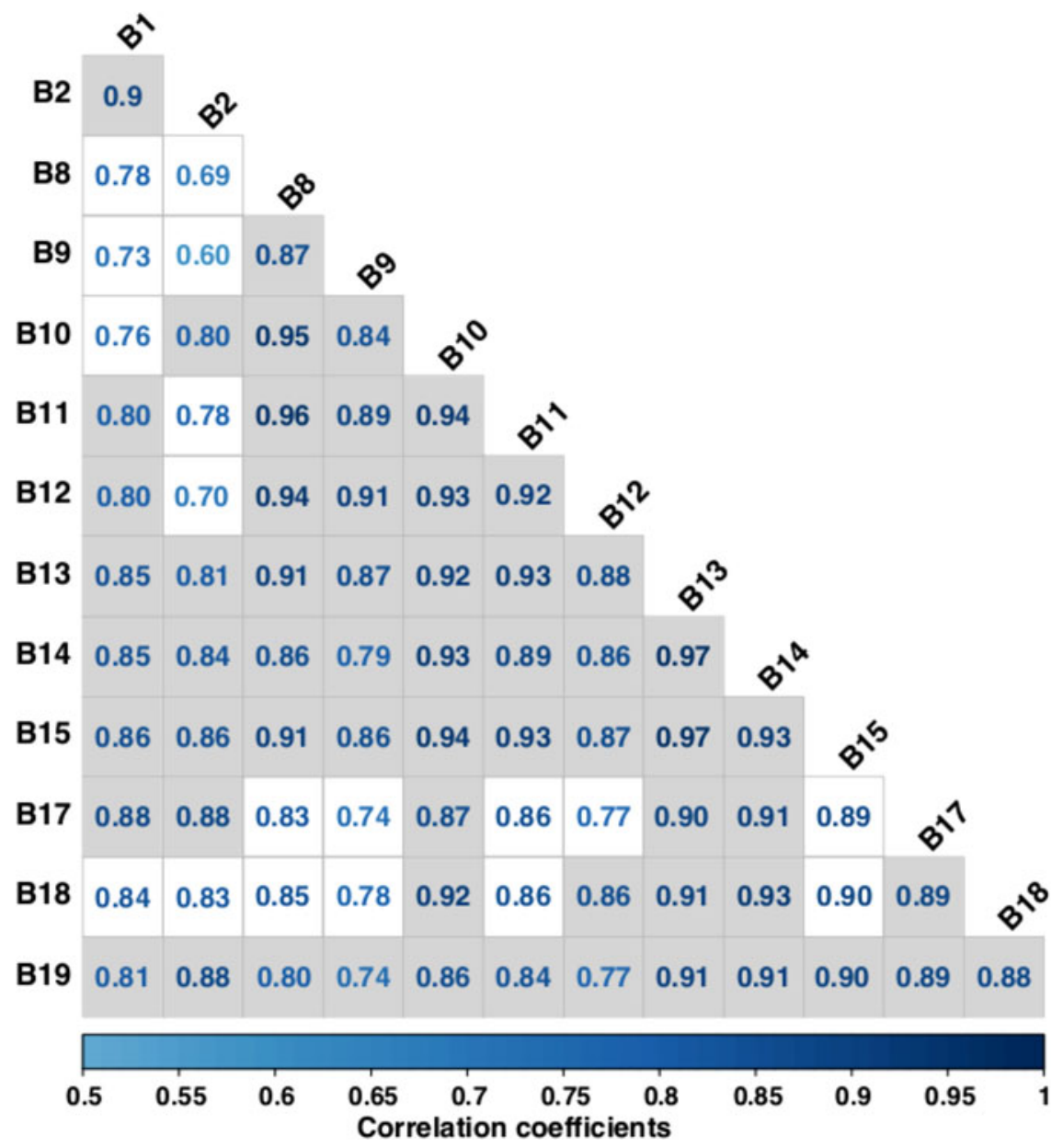

Fig. 3. Correlation between time series of mass-balance data measured at the individual stakes. Numbers inside grey squares are the ones that were actually used by the correlation technique.

- In a first step correlations were calculated between the time series of mass-balance measurements at the different stakes. The results are presented in Figure 3.

- At a given stake (e.g. stake $A)$, at dates with data gaps, the stake (stake B), which had data and whose data at the other dates correlated best with the given stake (stake A) was searched.

- The missing data were filled in by a linear trend between the data of stake $A$ and stake B, obtained from a linear least squares regression.

\subsubsection{Uncertainty assessment of the stake data}

We assume that the uncertainty of the stake data (Table 1 ) is $\sim 10 \%$ for the measured data, mostly due to uncertainties in the density. For the values inferred by the correlation technique we estimate the uncertainty $\sigma$ by the least squares estimator:

$$
\sigma=\sqrt{\frac{1}{n-2} \sum_{i=1}^{n}\left(A_{i}-\left(z_{1} B_{i}+z_{0}\right)\right)^{2}}
$$


Table 1. SMB data at the individual stakes; bold face numbers were measured and the italic values were inferred by the correlation technique; horizontal lines indicate the division in the four hydrological years analysed in this contribution.

\begin{tabular}{|c|c|c|c|c|c|c|c|c|c|c|c|c|c|c|}
\hline From & Until & B01 & B02 & B08 & B09 & B10 & B11 & B12 & B13 & B14 & B15 & B17 & B18 & B19 \\
\hline $26 / 04 / 2009$ & 9/05/2009 & 0.11 & -0.06 & 0.12 & -0.30 & -0.32 & -0.10 & -0.20 & -0.49 & -0.27 & -0.50 & -0.01 & -0.22 & -0.16 \\
\hline 29/05/2009 & $24 / 07 / 2009$ & 0.72 & 0.64 & 1.19 & 0.24 & 0.89 & 1.32 & 0.34 & 0.90 & 1.34 & 0.87 & 1.21 & 0.95 & 1.22 \\
\hline $24 / 07 / 2009$ & 2/09/2009 & 0.90 & 0.73 & 0.74 & 0.63 & 0.85 & & 0.25 & 1.42 & 1.72 & & 1.54 & 45 & 1.40 \\
\hline $02 / 0$ & $07 / 1$ & & & & & 0.33 & & & 0.63 & & .49 & 0.52 & 42 & 0.59 \\
\hline $07 / 10$ & $11 / 1$ & & & & & 0.31 & 0.45 & & & 1.78 & 0.67 & 1.21 & 10 & 1.74 \\
\hline $11 / 12 / 2009$ & 07/01/2010 & -0.11 & 0.10 & -1.01 & -1.06 & -0.70 & -0.94 & 0.82 & -0.78 & -0.41 & -0.67 & -0.50 & -0.48 & -0.37 \\
\hline 07/01/2010 & $11 / 02 / 2010$ & -0.65 & 0.12 & -1.76 & -2.05 & 1.00 & 1.16 & 1.99 & -0.98 & -0.66 & -0.92 & -0.54 & -0.89 & -0.69 \\
\hline $11 / 02 / 2010$ & 11/03/2010 & -0.07 & 0.10 & -1.45 & -2.04 & -1.12 & -1.67 & -1.52 & -0.88 & -0.78 & -0.75 & -0.13 & -0.58 & -0.61 \\
\hline $11 / 03 / 2010$ & $07 / 04 / 2010$ & -0.02 & -0.20 & -1.10 & -1.37 & -1.10 & -0.99 & -1.51 & -0.62 & -0.54 & -0.60 & -0.06 & -0.56 & -0.30 \\
\hline 07/04/2010 & 09/05/2010 & 0.51 & 0.52 & -0.07 & -0.42 & -0.03 & -0.01 & -0.26 & 0.20 & 0.30 & 0.16 & 0.45 & .31 & 0.67 \\
\hline 09/05/2010 & 28/05/2010 & 0.20 & 0.30 & 0.11 & 0.05 & 0.17 & 0.11 & 0.10 & 0.09 & $\mathbf{0}$ & 0.17 & 0.34 & .19 & 0.25 \\
\hline 28/05/2010 & $15 / 07 / 2010$ & 0.42 & 0.38 & 0.37 & 0.26 & 0.35 & 0.49 & 0.30 & 0.58 & 0.74 & 0.49 & 0.58 & .63 & 0.73 \\
\hline $15 / 07 / 2010$ & 02/09/2010 & 0.29 & 0.52 & 0.87 & 0.34 & 0.70 & 0.97 & 0.43 & 0.82 & 0.67 & 0.74 & 0.80 & 61 & 0.63 \\
\hline 9/2010 & 08/10/2010 & & 0.20 & -0.06 & -0.09 & 0.05 & -0.04 & & & & 0.10 & -0.03 & .20 & 0.14 \\
\hline 2010 & $04 / 11$ & & 0.16 & 0.09 & -0.13 & -0.02 & 0.05 & -0.19 & -0.04 & & 0.12 & & & 0.29 \\
\hline $04 / 11 / 2010$ & $06 / 12 / 2010$ & & 0.08 & -0.47 & -0.65 & -0.41 & -0.68 & -0.63 & -0.20 & & -0.46 & -0.04 & -0.13 & -0.02 \\
\hline 06/12/2010 & $22 / 12$ & & 0.05 & 0.04 & -0.11 & 0.14 & 0.09 & 0 & 0.05 & & 0.27 & -0 & 28 & 0.27 \\
\hline 2010 & $23 / 01$ & -0.54 & -0.59 & -0.61 & -1.06 & -1.03 & -0.86 & -0.65 & -0.15 & & -0.16 & -0.07 & -0.35 & -0.21 \\
\hline 2011 & $23 / 02 / 2011$ & 0.74 & 0.88 & -1.35 & -2.39 & -1.02 & -1.41 & -2 & -1.00 & -1 & -0.82 & -0.81 & 5 & -0.44 \\
\hline 011 & $24 / 0$ & -0.24 & -0.28 & -1.86 & $-\mathbf{0}$ & -1.72 & -1 & -1 & -0 & -0 & -1.14 & -0 & & -0.23 \\
\hline 11 & $01 / \mathrm{C}$ & & $\mathbf{0}$ & 0. & 0 & -0.04 & & 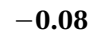 & & & 0.26 & 25 & 3 & 0.45 \\
\hline $01 /$ & $22 /$ & & 0 & 0. & -0 . & $\mathbf{0}$ & & $-\mathrm{c}$ & 3 & 8 & 5 & 4 & 5 & 0.39 \\
\hline 11 & $22 /($ & 0 & 0. & 0. & & 0 . & & & 3 & & 1 & $\mathbf{0}$ & 67 & 0.74 \\
\hline 11 & $19 /$ & 0 & 0.4 & 0. & & $\mathbf{0}$ & & & 0. & & 8 & 0. & 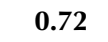 & 0.87 \\
\hline 11 & $20 /($ & & 0.4 & 0.5 & 0 & 0. & 0. & 0 & 0. & & 7 & 0. & 73 & 0.82 \\
\hline 011 & $07 / 0$ & 0.0 & 0.1 & 0.4 & 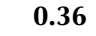 & 0.47 & 0.6 & 0.2 & 0 & 0 & 0 & 0.66 & 9 & 0.76 \\
\hline 011 & $13 / 1$ & 0.4 & 0.41 & 0.2 & -0.06 & 0.44 & 0.6 & 0.40 & 3 & 0.48 & 0.25 & 0.42 & 3 & 0.60 \\
\hline 13/10/2011 & $11 / 1$ & 0.2 & 0.14 & -0.24 & -0.58 & -0.21 & -0.75 & -0.04 & -0.26 & 0.19 & -0.31 & 0.54 & .73 & 0.64 \\
\hline 011 & $26 / 1$ & -0.39 & -0.43 & -1.77 & -1.97 & -1.39 & -2.4 & -1.73 & 1.32 & -0.75 & 1.04 & -0.70 & 8 & -0.92 \\
\hline & & -0.80 & -0.72 & -2.21 & -2.5 & -1.95 & -2 & -1.98 & -1.77 & -1 & -1.86 & -0.49 & $-\mathrm{c}$ & -1.51 \\
\hline 23/01/2012 & $10 / 0$ & -0.05 & -0.03 & -0.54 & -0.78 & -0.50 & -0.59 & -0.64 & -0.39 & -0.24 & -0.35 & -0.14 & -0.17 & -0.09 \\
\hline $10 / 02 / 2012$ & $07 / 03 / 2012$ & -0.66 & -0.55 & -1.73 & -1.98 & -1.44 & -1.86 & -1.69 & -1.67 & -1.51 & -1.53 & -0.49 & -1.22 & -1.00 \\
\hline 07/03/2012 & $02 / 04 / 2012$ & -0.69 & -0.33 & -1.20 & -1.17 & -1.13 & -1.27 & -1.19 & -1.48 & -1.41 & -0.86 & -1.19 & -0.79 & -0.93 \\
\hline 02/04/2012 & $21 / 04 / 2012$ & 0.08 & 0.12 & -0.44 & -0.50 & -0.53 & -0.66 & -0.49 & -0.41 & -0.27 & -0.31 & -0.27 & -0.27 & -0.15 \\
\hline $21 / 04 / 2012$ & 23/05/2012 & 0.25 & 0.19 & -0.01 & 0.04 & 0.00 & 0.03 & -0.09 & 0.05 & 0.06 & 0.22 & 0.29 & 0.27 & 0.36 \\
\hline 012 & $25 / 0$ & 0.34 & 0.45 & 0.42 & 0.02 & 0.31 & 0.44 & 0.31 & 0.52 & 0.90 & 0.39 & 0.87 & .80 & 0.67 \\
\hline 25/06/2012 & 26/07/2012 & 0.38 & 0.44 & 0.18 & 0.47 & 0.50 & 0.44 & 0.09 & 0.48 & 0.85 & 0.46 & 0.40 & 0.78 & 0.80 \\
\hline 012 & $24 / 0$ & 0.21 & 0.20 & 0.29 & 0.21 & 0.37 & 0.38 & 0.22 & 0.43 & 2 & 0.36 & 0.48 & .38 & 0.59 \\
\hline & $22 / 0$ & & 0.27 & 0.35 & & & & & 0.35 & & & 0.25 & 7 & 0.2 \\
\hline & $27 / 1$ & & 0.0 & & 0 & -0.14 & 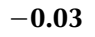 & & & & -0.11 & 0.24 & 4 & 0.3 \\
\hline 2012 & $11 / 1$ & & 0.0 & -0.1 & $-\mathbf{0}$ & & -0.22 & -0.21 & $-\mathbf{0 . 0 7}$ & & -0.21 & 0.03 & .03 & 0.0 \\
\hline $11 / 11 / 2012$ & $08 / 1$ & & 0.1 & & -0 & 0.10 & & -0.61 & -0.27 & & -0.37 & 0.17 & 5 & 0.11 \\
\hline 012 & & & & -0.4 & -2 & 0.24 & -0 & $-x$ & & & -0 & 0.26 & 8 & 0.05 \\
\hline $1 / 2013$ & $05 / 02 / 2013$ & -0.65 & -0.56 & -2.02 & -2.35 & -1.68 & -2.17 & -2.07 & -1.59 & -1.53 & -1.44 & -1.12 & -1.22 & -1.08 \\
\hline & 02/03/2013 & 0.31 & -0.13 & -2.06 & -2.39 & -1.53 & -1.90 & -2.11 & -0.92 & -1.07 & -0.83 & -0.77 & -0.85 & -0.31 \\
\hline & & & -0.12 & -0.4 & -0 . & -0.41 & -0 & -0 & -0.57 & -0.39 & -0 & -0.54 & -0.54 & -0.12 \\
\hline $22 / 03 / 2013$ & $28 / 04 / 2013$ & -0.59 & -0.49 & -1.23 & -1.33 & -1.55 & -1.40 & -1.13 & -1.04 & -1.15 & -0.66 & -0.74 & -0.95 & -0.34 \\
\hline
\end{tabular}

where $A_{i}$ and $B_{i}$ are measured data at Stake A and Stake B, respectively at the dates where both stakes where found, $n$ is the number of these dates and $z_{1}$ and $z_{0}$ are the coefficients of the linear least squares regression. The uncertainty of the annual SMB obtained at the individual stakes $\sigma_{\mathrm{a}}$ was calculated according to the Gauss formula for propagation of errors according to:

$$
\sigma_{\mathrm{a}}=\sqrt{\sum_{i=1}^{N}\left(\sigma_{i}\right)^{2}},
$$

where $\sigma_{i}$ is the uncertainty of the value obtained at the ith visit and $N$ is the number of visits in the year. The uncertainty of the annual glacier $\mathrm{SMB} \sigma_{\mathrm{a}}^{\mathrm{G}}$ obtained from the interpolation of stake data was estimated by:

$$
\sigma_{\mathrm{a}}^{\mathrm{G}}=\frac{1}{13} \sqrt{\sum_{i=1}^{13}\left(\sigma_{\mathrm{a}}^{i}\right)^{2}},
$$

where $\sigma_{\mathrm{a}}^{i}$ denotes the uncertainty of the annual SMB obtained at the 13 different stakes used in this study.

\subsubsection{SMB Model}

A distributed mass-balance model (Machguth and others, 2006b; Paul and others, 2009) was used to model the SMB 
of Mocho Glacier. The model calculates the mass balance $b$ (C) on every grid cell $C$ of a DEM, which had a resolution of $30 \mathrm{~m}$ in our case (Tachikawa and others, 2011). For every day in the modelling period we calculated $b(C)$ according to:

$$
b(C)=c(C)-a(C) .
$$

The two constituting terms of Eqn (4), accumulation $C(C)$ and ablation $a(C)$, are calculated as follows.

The accumulation $c(C)$ is estimated to be the solid precipitation since the glacier is located in a temperate climate zone so that it is assumed that rain runs off the glacier without refreezing and thus without contributing to accumulation. Solid precipitation is defined as a fraction of the total precipitation $P(C)$ according to:

$$
C(C)=q[T(C)] \cdot P(C) .
$$

Here $q[T(C)]$ is a function that varies between 0 and 1 and depends on the temperature $T$ of every grid cell. Dai (2008) empirically found a function with the shape of a hyperbolic tangent for the rain/snow transition. Based on his findings we used the following formula:

$$
q[T(C)]=-0.5 \cdot \tan h(\beta \cdot(T(C)-\gamma)-\delta)+0.5,
$$

with $\beta=0.72, \gamma=1.17$ and $\delta=1.00$. Figure 4 shows the graph of $q(T)$.

To calculate the ablation $a(C)$ on every grid cell $C$, a simplified energy-balance approach is applied (Oerlemans, 2001). Of the incoming solar radiation a fraction which depends on the surface albedo $\alpha_{\text {surf }}(C)$ is absorbed by the glacier surface (see Eqn (7)). It is assumed that there is either snow or firn or ice on the grid cells excluding intermediate states. Based on the values provided in Cuffey and Paterson (2010), we chose the following three values: $\alpha_{\mathrm{s}}=$ 0.7 for snow, $\alpha_{\mathrm{f}}=0.45$ for firn and $\alpha_{i}=0.3$ for ice.

Furthermore, the model assumes a linear dependence of the sum of the long-wave radiation balance and the turbulent heat fluxes (sensible and latent heat fluxes) of every grid cell on the temperature of the grid cell:

$$
a(C)=\left[1-\alpha_{\text {surf }}(C)\right] \cdot S W_{\text {in }}(C)+C_{1} \cdot T(C)+C_{0} .
$$

Here $S W_{\text {in }}$ denotes the incoming solar (short-wave) radiation and $C_{1}$ and $C_{0}$ are open model parameters.

The input data grids of $S W_{\text {in }}$ and $T$ are derived from the measurements at the Mocho1-AWS as follows. For the temperature a linear variation with elevation is assumed:

$$
T(C)=T_{\text {Mocho } 1}+\left(z_{\text {Mocho1 }}-z(C)\right) \cdot \operatorname{lr} T
$$

where $z(C)$ denotes the elevation of the grid cell, $z_{\text {Mocho1 }}$ is the elevation of the Mocho1-AWS, $T_{\text {Mocho1 }}$ is the daily mean temperature measured at the Mocho1-AWS and $I r_{\mathrm{T}}=0.67^{\circ} \mathrm{C}(100 \mathrm{~m})^{-1}$ is the temperature lapse rate, which was determined by a linear fit between daily temperature data from Mocho1-AWS and Mocho2-AWS.

To distribute the incoming solar radiation, daily clear-sky solar radiation was calculated using a code developed by Corripio (2003). The calculated daily clear-sky solar radiation at the Mocho1-AWS was compared with the measured incoming short-wave radiation defining a factor of atmospheric transmissivity:

$$
\tau=\frac{S W_{\text {in }}^{\text {meas }}}{S W_{\text {in }}^{\text {clear }}} .
$$

Finally the incoming solar radiation at every grid cell was obtained by multiplying the calculated clear-sky incoming radiation by the factor of atmospheric transmissivity $\tau$ :

$$
S W_{\text {in }}(C)=\tau \cdot S W_{\text {in }}^{\text {clear }}
$$

The precipitation in every grid cell was inferred using the measurements from the PFuy-AWS. Due to our observations on the glacier that accumulation increases up to a certain elevation and decreases for higher elevations we assume a linear dependence of precipitation on elevation, increasing until $2000 \mathrm{~m}$ a.s.l. and decreasing from $2000 \mathrm{~m}$ a.s.l. until the summit (2400 $\mathrm{m}$ a.s.l.):

$$
\begin{aligned}
& P(C)= \\
& \begin{cases}P_{\text {PFuy }}\left(1+\left(z(C)-Z_{\text {PFuy }}\right)\right) / r_{\mathrm{P}}, & 600 \mathrm{~m} \leq z \leq 2000 \mathrm{~m} \\
\left.P_{2000}-P_{\text {PFuy }}(z(C)-2000)\right) / r_{\mathrm{P}}, & 2000 \mathrm{~m} \leq z \leq 2400 \mathrm{~m}\end{cases}
\end{aligned}
$$

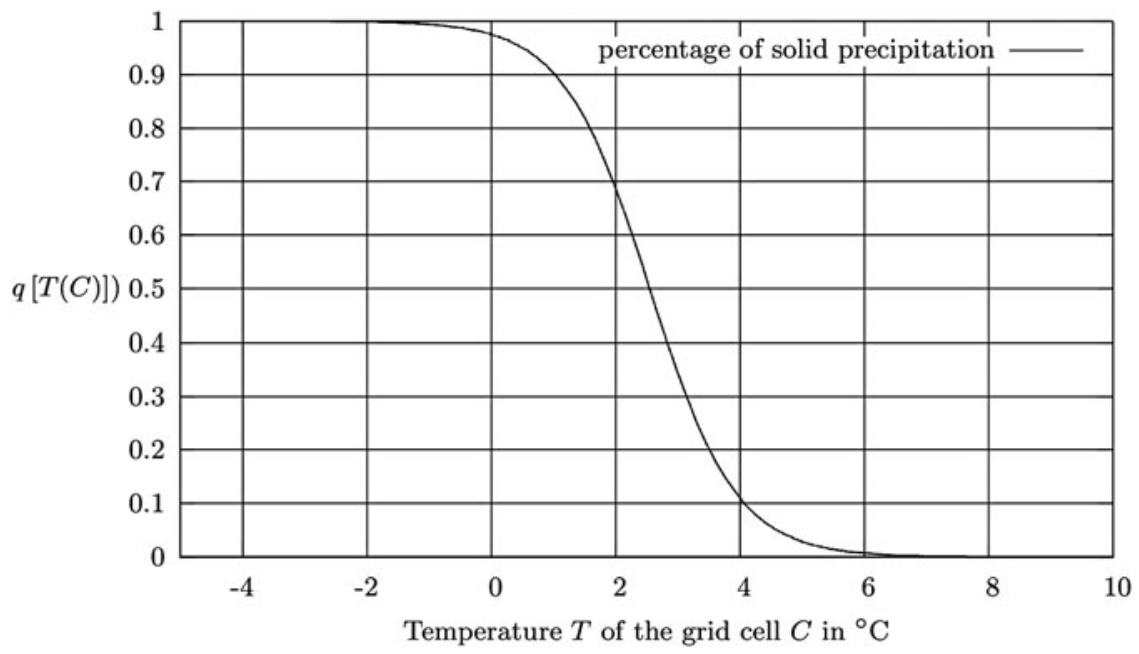

Fig. 4. Percentage of solid precipitation as a function of temperature (adapted from Dai (2008)). 

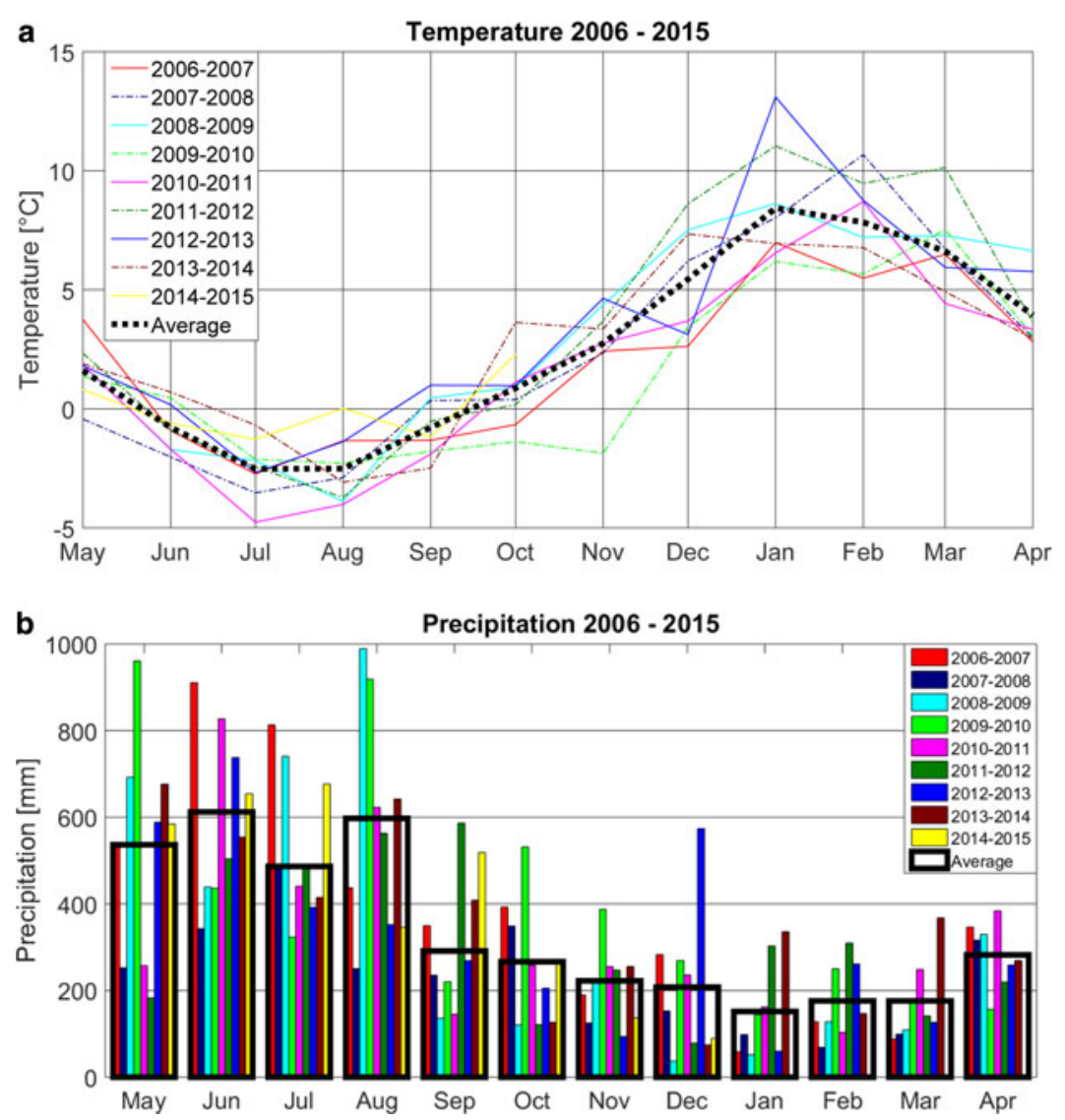

Fig. 5. Climate at Mocho Glacier from 2006 to 2015: black dotted line (a) and black boxes (b) indicate averaged values. (a) Monthly mean temperatures at Mocho1-AWS (b) Monthly precipitation sums at PFuy-AWS.

Here $P_{\mathrm{PFuy}}$ is the daily precipitation measured at PFuy-AWS, $Z_{\text {PFuy }}$ is the elevation of the PFuy-AWS $(600 \mathrm{~m})$ and $/ r_{\mathrm{P}}$ is the precipitation lapse rate. $P_{2000}=P_{\text {PFuy }}\left(1+\left(2000 \mathrm{~m}-z_{\text {PFuy }}\right)\right)$ $I r_{\mathrm{P}}$. Since $I r_{\mathrm{P}}$ is difficult to determine experimentally and can vary significantly from one storm to another, this parameter is an open model parameter, which is determined by the comparison of the model results with the results of the measurements (see Section 3.3).

\section{RESULTS}

\subsection{Climate}

In Figure 5a we present monthly mean air temperatures measured between 2006 and 2015 at Mocho1-AWS at 1970 m.a.s.l.

The mean air temperature in this period is $2.6^{\circ} \mathrm{C}$ and the typical yearly course of the monthly mean temperature (black dashed line) has a sinusoidal shape with an amplitude of $\sim 5^{\circ} \mathrm{C}$. Mean monthly precipitation sums measured at PFuy-AWS are presented in Figure 5b. The mean annual precipitation sum from 2006 to 2015 measured at Puerto Fuy is $\sim 4000 \mathrm{~mm}$. Large interannual variations of the monthly precipitation sums are visible in Figure 5b. On average, the monthly precipitation sums show a clear seasonal signature with very high precipitation amounts in winter and lower amounts in summer.

\subsection{Measured annual mass balance}

In Figure 6 we present the SMB inferred from the massbalance data at the individual stakes (see Table 1) for four different hydrological years. An interpolation of the stake data to the entire catchment of the Mocho Glacier for the four hydrological years was realized using the kriging method. As beginning of the hydrological year we chose the field campaign whose date was closest to 1 May, because on average the inferred glacier SMB changes from negative to positive close to that date. We observe a high variability of the distributed SMB on Mocho Glacier in the four hydrological years that are presented in Figure 6 . The annual SMB of Mocho Glacier was positive in 2009/10, near to zero in 2010/11 and clearly negative in 2011/12 and 2012/13 (Table 2). The division of the glacier into accumulation and ablation areas by the equilibrium line varies accordingly: in 2009/10 large parts of the glacier accumulate mass while in 2011/12 and 2012/13 the accumulation area is small compared with the total area of the glacier. The mean measured annual SMB in these 4 years was $-0.90 \mathrm{~m}$ w.e. $\mathrm{a}^{-1}$. The mean measured accumulation on the glacier was $2.88 \mathrm{~m}$ w.e. $\mathrm{a}^{-1}$ and the mean ablation $3.78 \mathrm{~m}$ w.e. $\mathrm{a}^{-1}$ during the same period. In Figure 7 we present the mean measured accumulation and ablation distributed on the glacier, which was also generated by interpolating the stake data with the kriging method. As expected, ablation shows a strong altitudinal dependence. Accumulation however is highest not at the summit of the Mocho Volcano but at Stake 19 and second highest at Stake 14 well in the centre of the glacier. This is probably due to the fact that during snow storms the predominant wind direction is northwest and snow drifts and accumulates at protected locations of the glacier. Due to the presumably very strong winds at the summit of Mocho Volcano, 

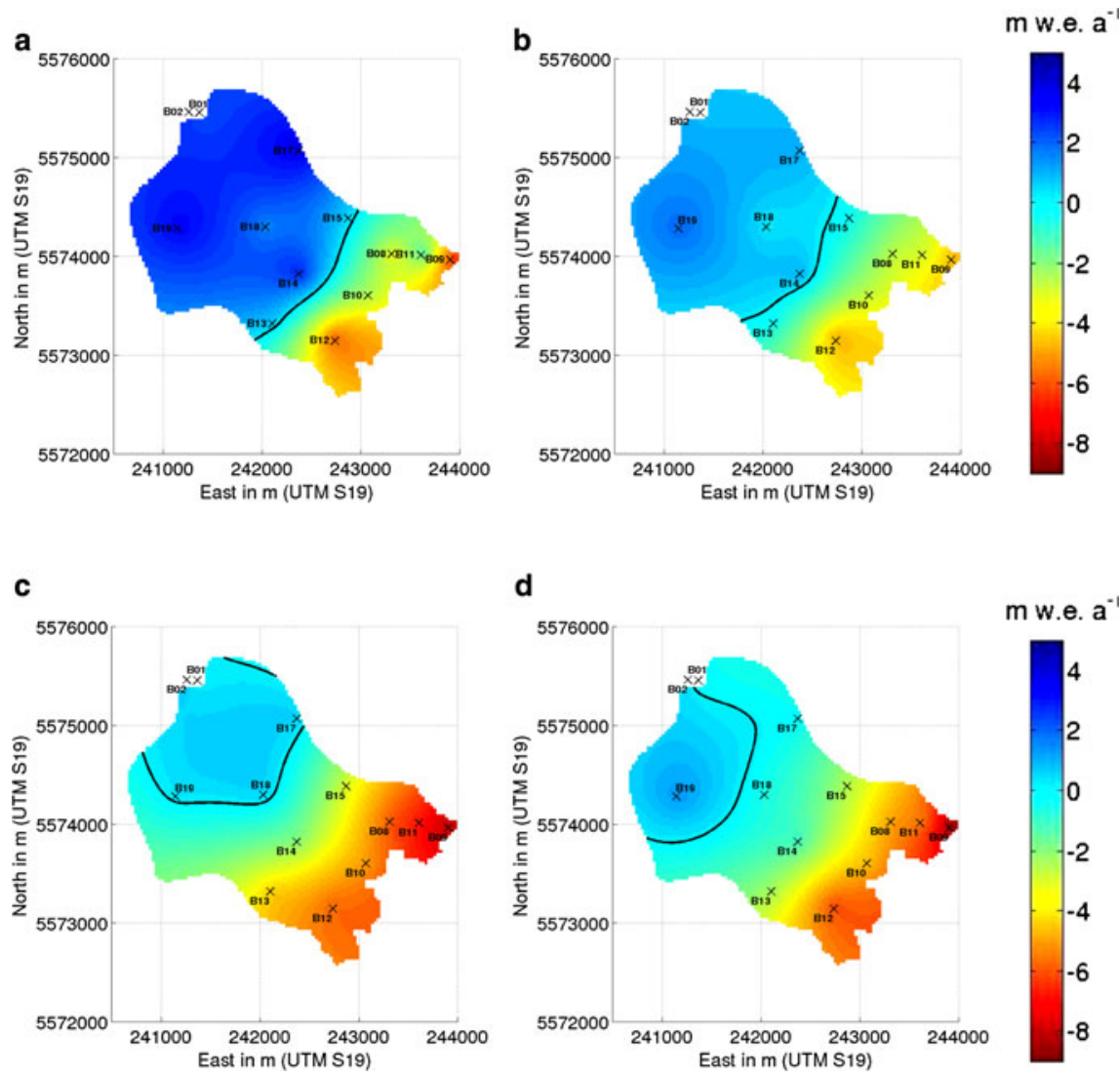

Fig. 6. Patterns of annual surface mass balance inferred from the stake measurements; equilibrium line in black. (a) 2009/10 (b) 2010/11 (c) 2011/12 (d) 2012/13.

Table 2. Annual glacier mass balance inferred from the stake network and the SMB model and annual meteorological data for the four hydrological years 2009/10-2012/13

\begin{tabular}{|c|c|c|c|c|c|c|}
\hline $\begin{array}{l}\text { Hydrological } \\
\text { year }\end{array}$ & $\begin{array}{l}\text { SMB stakes } \\
\text { m w.e. } a^{-1}\end{array}$ & $\begin{array}{l}\text { SMB model } \\
\text { m w.e. } a^{-1}\end{array}$ & $\begin{array}{c}\text { Mean temperature } \\
\text { Mocho1-AWS } \\
{ }^{\circ} \mathrm{C}\end{array}$ & $\begin{array}{c}\text { Annual Precipitation } \\
\text { PFuy-AWS } \\
\text { mm }\end{array}$ & $\begin{array}{c}\text { ELA } \\
\text { (stakes) } \\
\text { m }\end{array}$ & AAR \\
\hline $2009 / 10$ & $0.69 \pm 0.10$ & 1.18 & 1.51 & 4780 & $1904 \pm 15$ & 0.69 \\
\hline 2010/11 & $-0.37 \pm 0.11$ & 0.01 & 1.63 & 3941 & $1927 \pm 14$ & 0.63 \\
\hline $2011 / 12$ & $-2.14 \pm 0.14$ & -2.42 & 3.45 & 3737 & $2076 \pm 98$ & 0.31 \\
\hline $2012 / 13$ & $-1.79 \pm 0.11$ & -2.38 & 3.40 & 3918 & $2065 \pm 98$ & 0.25 \\
\hline Mean & -0.90 & -0.90 & 2.75 & 4094 & 1993 & 0.47 \\
\hline
\end{tabular}

Equilibrium line altitude (ELA) and accumulation area ratio (AAR) were calculated from the stake data.

accumulation is higher on the more protected lower parts of the plateau.

\subsection{Model}

SMB models try to quantify climate/glacier interactions. The model described in Section 2 is a semi-empirical SMB model, which considers the meteorological observations of air temperature and incoming solar radiation near the glacier as well as precipitation in the valley to compute the SMB of Mocho Glacier. In Figure 8 we present the course of the modelled glacier average SMB for each of the hydrological years 2006/07-2014/15 and glacier average SMB obtained when running the model with 2006/07-2014/15 average climate data (black dashed line). We observe a high interannual variability of the modelled annual glacier SMB. In Table 2 we compare the modelled annual glacier SMB with the results inferred from the stake measurements: as in the latter, the simulated mass balance for 2009/10 gives a positive glacier SMB, 2010/11 a glacier SMB near to zero and 2011/12 and 2012/13 clearly negative values. However the differences between the measured and the modelled annual balances are much higher than the estimated uncertainties of the measured values. The glacier SMB obtained from 2006/07 to 2014/15 average climate data (black dashed line) shows mean glacier accumulation of $3.5 \mathrm{~m}$ w.e. taking place until the middle of September. Ablation starts in the beginning of November and lasts until the end of April. The glacier average ablation is greater in magnitude than the accumulation resulting in a negative glacier SMB.

The open model parameters $C_{1}, C_{0}$ and $/ r_{\mathrm{p}}$ were chosen so that (1) the mean modelled annual glacier SMB during the four hydrological years 2009/10 and 2012/13 coincides best with the mean annual glacier SMB inferred from the 

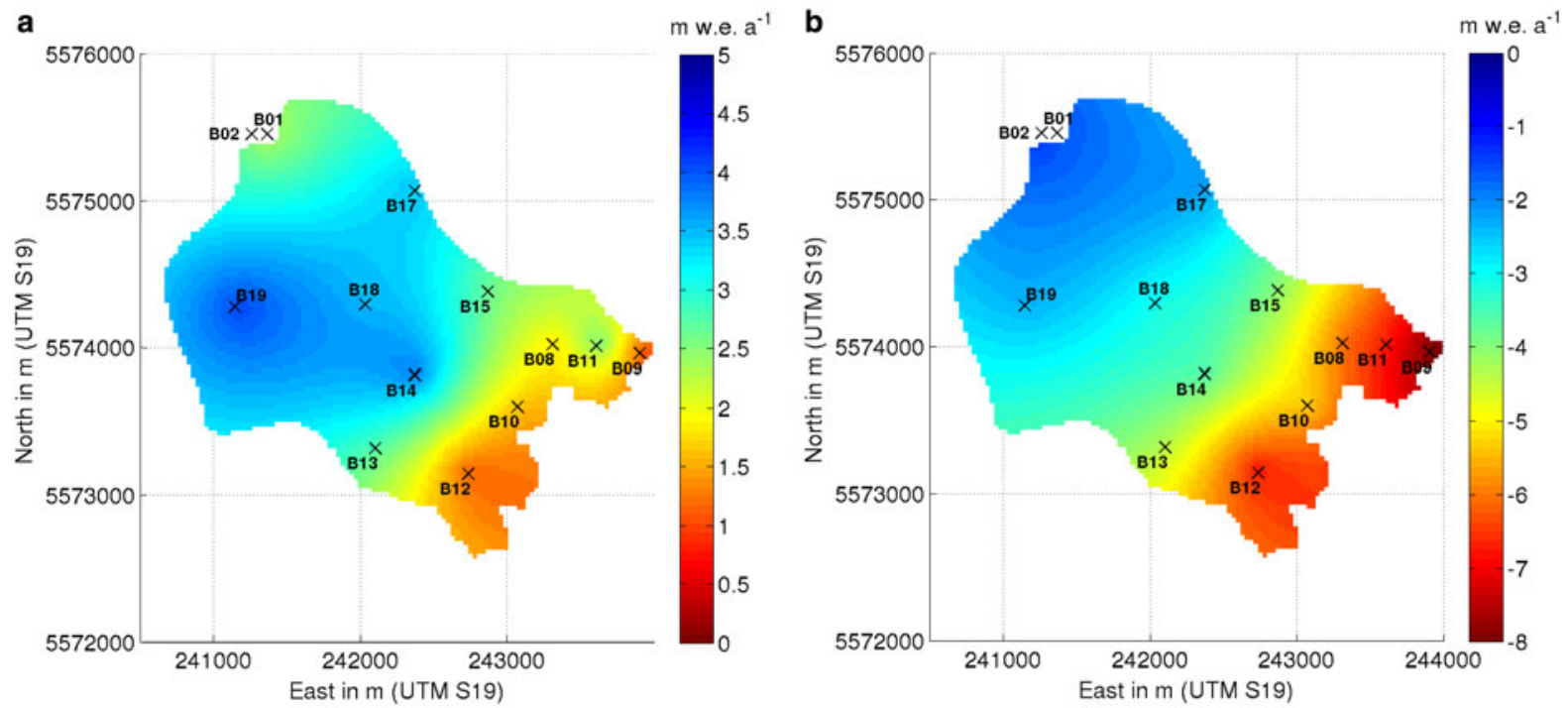

Fig. 7. Patterns of accumulation and ablation measured on Mocho Glacier 2009-13. (a) Accumulation (b) Ablation.

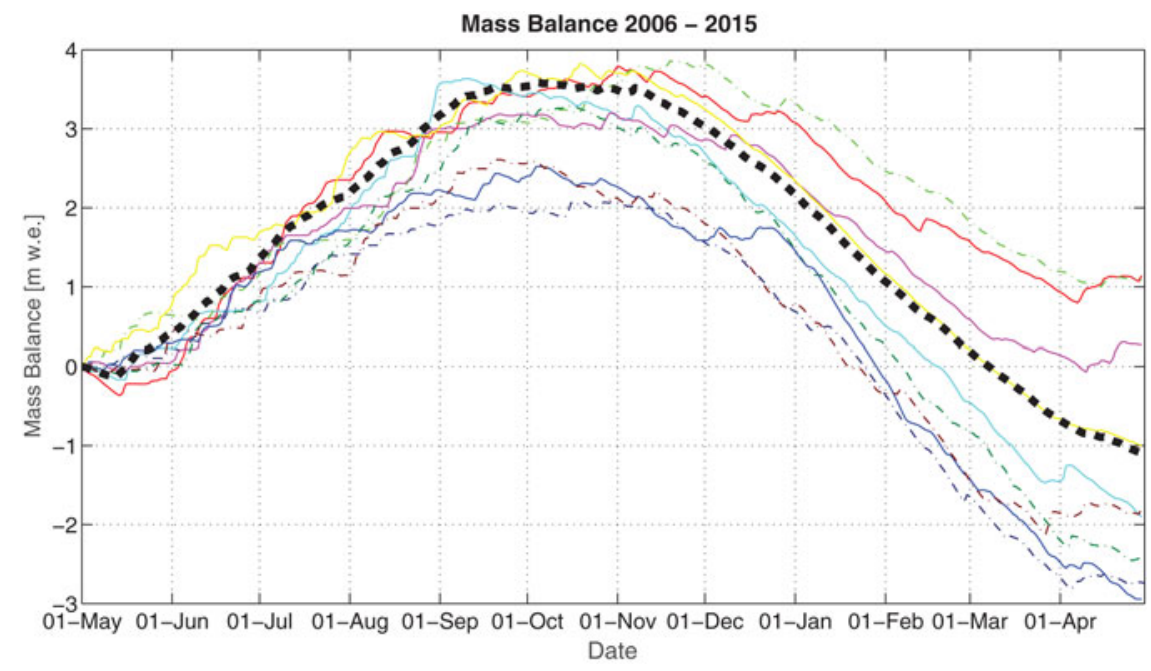

Fig. 8. Course of the modelled glacier mass balances 2006/07 to 2014/15.

stake measurements and (2) the sum of quadratic deviations between measured and modelled annual glacier SMB was minimized. When comparing the measured and modelled annual SMB on Mocho Glacier with the meteorological values from the AWSs (Table 2), we can note that the two strongly negative years $2011 / 12$ and $2012 / 13$ were clearly warmer than the preceding years 2009/10 and 2010/11. On the other hand, the clearly positive year 2009/10 had much higher annual precipitation than the other 3 years.

To learn more about the results produced by the simple SMB model, in Figure 9 we compare the 2009-13 average $S M B$ pattern inferred from the stake measurements with the 2009-13 average SMB pattern produced by the SMB model. Although there are some similarities, some striking differences are visible:

- The modelled SMB map has much more detailed features than the SMB inferred from the interpolation of the stake data.

- The altitudinal gradient of SMB is higher in the map inferred from the stake data.

\section{DISCUSSION AND CONCLUSIONS}

In this contribution we presented climate and SMB data for Mocho Glacier $\left(40^{\circ} \mathrm{S}\right)$ in the Chilean Lake District. To our knowledge this is the first publication of climate data measured at high elevation ( 2000 m a.s.l.) in the Patagonian Andes. The mean annual temperature from 2006 to 2015 at Mocho1-AWS on a nunatak of Mocho Glacier was $+2.6^{\circ} \mathrm{C}$. The mean annual precipitation sum of $4000 \mathrm{~mm}$ measured at PFuy-AWS $(13 \mathrm{~km}$ from Mocho Glacier at $600 \mathrm{~m}$ a.s.l.) is higher than the annual precipitation sum at several coastal stations in Patagonia (Rosenblüth and others, 1995; Carrasco and others, 2002; Aravena and Luckman, 2009) and nearly double the amount measured in Valdivia (González-Reyes and Muñoz, 2013), a coastal station at the same latitude. This shows the strong orographic influence on the precipitation measured at the inland weather stations, which was studied in detail for the subtropical and extratropical Andes by Viale and Garreaud (2015).

The annual variations of relevant climate data used for the modelling of the SMB of Mocho Glacier are compared with 

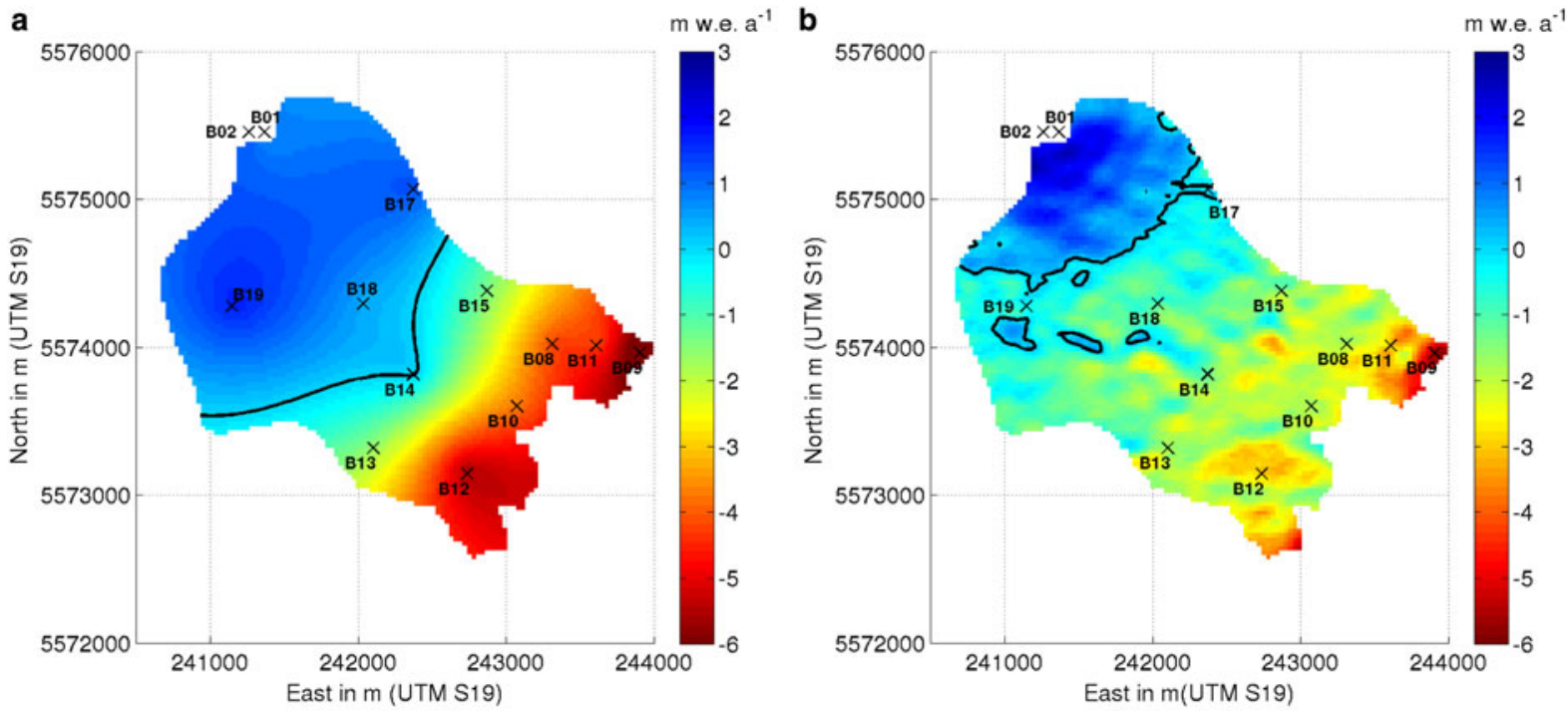

Fig. 9. Measured and modelled mean surface mass-balance map over Mocho Glacier. Black line denotes the equilibrium line $(b=0)$. (a) Stakes: 2009-13 (b) Modelled: 2009-13.

other climate data in the region in Figure 10. The annual mean temperature measured at Mocho1-AWS shows very similar variation to the variations of the annual mean temperature at the $850 \mathrm{~Pa}$ level of the upper-air soundings made each day in Puerto Montt at $12 \mathrm{~h}$ UTC. The average elevation of this pressure level above Puerto Montt is $\sim 1500 \mathrm{~m}$. The Pearson correlation coefficient $r$ between the two signals is 0.85 . Also the annual mean temperature in Valdivia and Temuco show similar variations $(r=0.82$ and $r=0.76$, respectively). Please note that these two signals have been shifted by $10^{\circ} \mathrm{C}$ in Figure 10a for a better visualization of the variation of the signals. Similar variation of annual precipitation is observed at PFuy-AWS as compared with the coastal station Valdivia and the station in Riñihue which is about half way from Valdivia to Puerto Fuy (see Fig. 1a).

The annual mass-balance values inferred from the stake network confirm the high interannual variability of SMB on Mocho Glacier observed already in preliminary studies (Rivera and others, 2005; Bown and others, 2007). This stresses the importance of long measurement series. However, even in this short 4-year time period a negative average $\mathrm{SMB}$ is observed, which agrees with the earlier observed

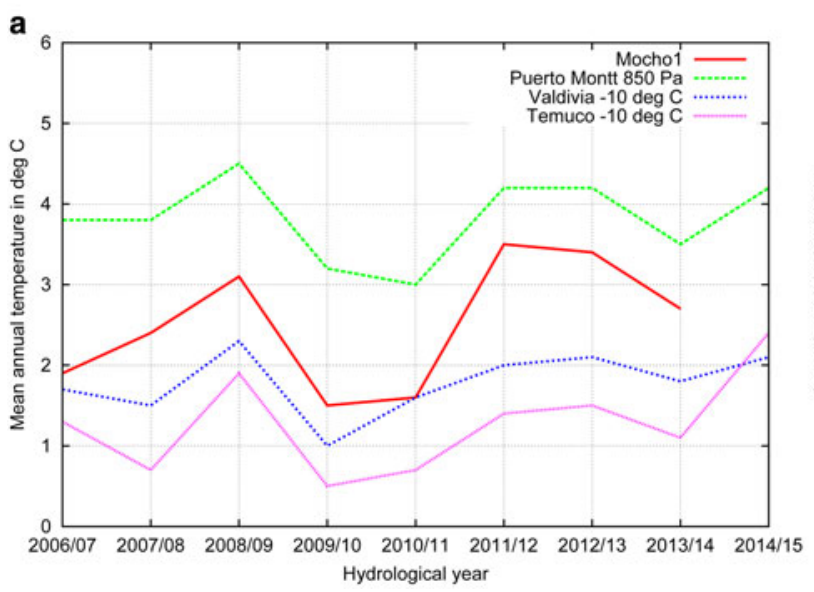

reduction in ice extent of the Mocho-Choshuenco ice cap (Rivera and others, 2005).

In Figure 11 we compare the measured and modelled annual SMB at Mocho Glacier with both measured and modelled annual SMB values for other ice bodies in the region. The measured SMBs were obtained from the World Glacier Monitoring Service (Zemp and others, 2015) and the modelled SMB of NPI is from Schaefer and others (2013). The modelled SMB at Mocho Glacier shows positive correlation with the modelled SMB of the NPI $(r=0.65)$ and the measured SMB at Martial Este Glacier in Tierra del Fuego $(r=$ 0.45). The measured SMB at Mocho Glacier shows slightly positive correlation with the SMB measured at Echaurren Norte Glacier in the Central Andes $(r=0.28)$. Correlation was negative between both measured and modelled SMB of Mocho Glacier and the glaciers Guanaco and Los Amarillos in the north of Chile (not shown in Fig. 11). This is interesting since it seems to indicate that the variation of Mocho's SMB is more similar to the variation of the SMB of Martial Este Glacier, $2000 \mathrm{~km}$ to the south than to that of Echaurren Norte Glacier with is only $700 \mathrm{~km}$ to the north. However some care has to be taken with this interpretation, considering that we have only a 9-year record of modelled

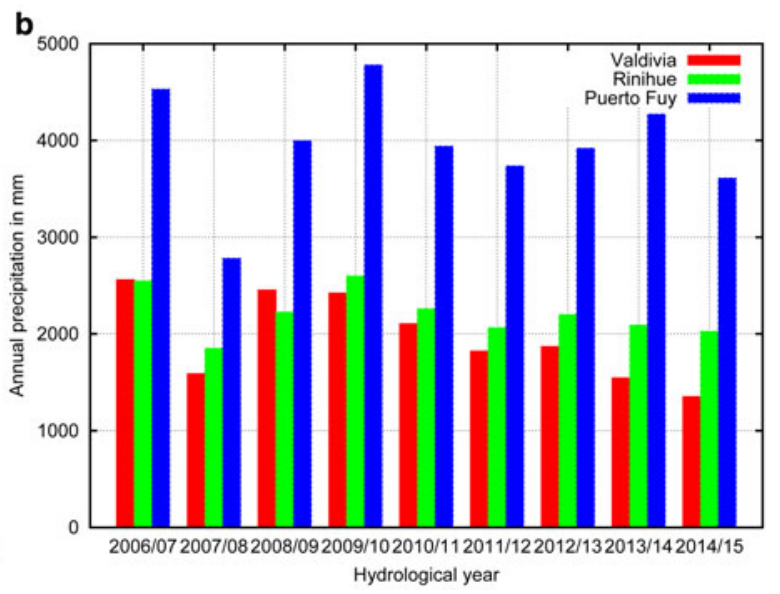

Fig. 10. Yearly climate data measured at several AWS in the region. (a) Annual mean temperature (b) Annual precipitation. 


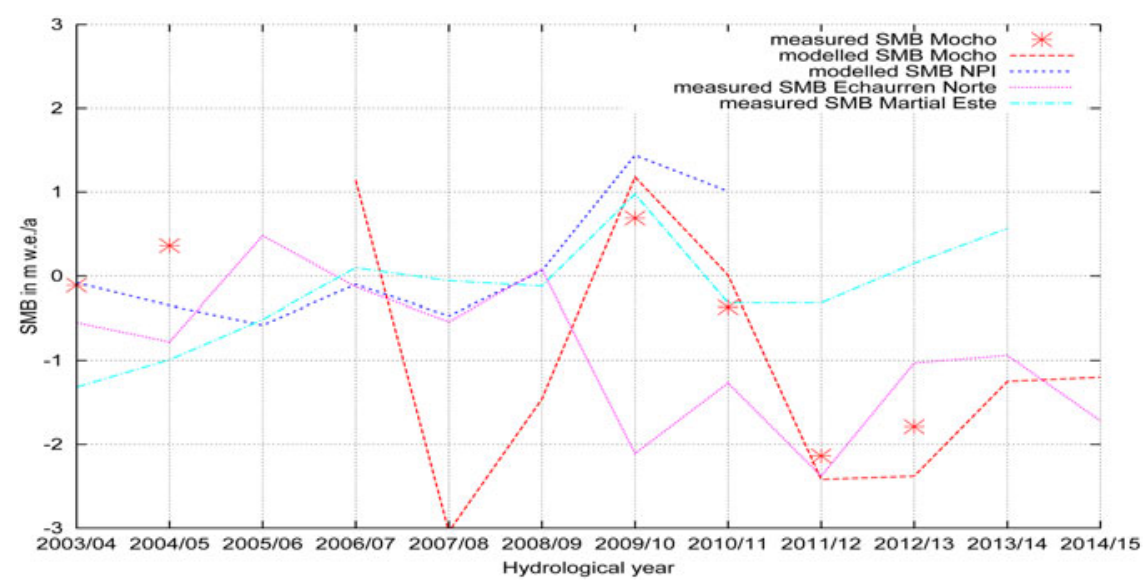

Fig. 11. Measured and modelled annual surface mass balance for some ice bodies in the Southern Andes.

SMB data from Mocho Glacier so far. Also correlation between the measured SMB at Mocho and that measured at Martial Este is not significant.

The simple SMB model seems to be adequate to predict variations of the annual SMB of Mocho Glacier, however it fails to predict SMB correctly at the different stakes. This is not surprising since the model is based on several assumptions, which provide strong simplifications of the physical processes, which determine glacier surface ablation and accumulation. As mentioned before, the altitudinal enhancement factor for orographic precipitation $/ r_{\mathrm{P}}$ is probably not constant either in time or in space. On the other hand, the snow which falls on Mocho Glacier can be redistributed by the strong wind registered at Mocho1-AWS (mean and maximum wind speeds in July were 36 and $115 \mathrm{~km} \mathrm{~h}^{-1}$, respectively). This is probably the reason why the measured accumulation decreases above a certain elevation. The parametrization of the processes, which cause surface ablation is very much simplified, as well. Although both the net long-wave radiation balance and the turbulent fluxes somehow depend on the temperature of the atmosphere at the surface, it is by no means clear that this dependence is linear. Perhaps trying to use stronger dependence of the SMB on temperature might improve the capability of the model to reproduce altitudinal gradients of SMB. The turbulent fluxes of course depend as well on other meteorological variables such as wind and relative humidity, which are not considered in our model. A strong feature of the model, however, is the explicit consideration of the short-wave net radiation, which predicts features in the SMB map, which have certain similarity to snow-ice patterns at the end of the hydrological year (Scheiter, 2016).

Further studies on Mocho Glacier will improve this capability of the model to reproduce realistic SMB maps by including a more physical parametrization of snow drift. Also the different components of the surface energy balance will be explicitly quantified at different locations of Mocho Glacier and for the different stages of the year.

\section{ACKNOWLEDGEMENTS}

The authors thank the Huilo-Huilo Biological Reserve for the support of the field activities by facilitating access to the glacier and infrastructure and Antonio Vasquez for his untiring support in the field campaigns during more than 10 years. We also want to thank Jorge Carrasco (DMC) for providing the temperature data of Puerto Montt and Valdivia and the WGMS for providing updated mass-balance data of other glaciers in the region. Pablo Iribarren's help with Figure 1a and Alvaro Gonzalez' help with Figure 3 are acknowledged. Duilio Fonseca helped formatting Table 1. The science presented in this work is supported by the internal research project of Austral University DID 2015-72. Marius Schaefer is Fondecyt Research Fellow (Grant No. 3140135).

\section{REFERENCES}

Aravena JC and Luckman BH (2009) Spatio-temporal rainfall patterns in Southern South America. Int. J. Climatol., 29(14), 2106-2120 (doi: 10.1002/joc.1761)

Bown F, Rivera A, Acuña C and Casassa G (2007) Recent glacier mass balance calculations at Volcán Mocho-Choshuenco $\left(40^{\circ}\right.$ S), Chilean Lake District. In Ginot P and Sicart J, eds. Glacier mass balance changes and meltwater discharge, vol. 318. IAHS, Wallingford, Oxfordshire, 143-152

Carrasco J, Casassa G and Rivera A (2002) Meteorological and Climatological aspects of the Southern Patagonia Icefield. In The patagonian icefields a unique natural laboratory for environmental and climate change studies. Kluwer Academic/Plenum Publishers, New York, 29-41

Corripio J (2003) Vectorial algebra algorithms for calculating terrain parameters from dems and solar radiation modelling in mountainous terrain. Int. J. Geograph. Info. Sci., 17(1), 1-23 (doi: $10.1080 / 713811744)$

Cuffey K and Paterson W (2010) The physics of glaciers. Elsevier, Oxford

Dai A (2008) Temperature and pressure dependence of the rain-snow phase transition over land and ocean. Geophys. Res. Lett., 35(12), L12802 (doi: 10.1029/2008GL033295), 112802

Davies BJ and Glasser N (2012) Accelerating shrinkage of patagonian glaciers from the little ice age (ad1870) to 2011. J. Glaciol., 58(212), 1063-1084 (doi: 10.3189/2012JoG12J026)

González-Reyes A and Muñoz AA (2013) Cambios en la precipitación de la ciudad de Valdivia (Chile) durante los últimos 150 años. BOSQUE, 34(2), 191-200 (doi: 10.4067/ S0717-92002013000200008)

Heucke E (1999) A light portable steam-driven ice drill suitable for drilling holes in ice and firn. Geogr. Ann.: Ser. A, Phys. Geography, 81(4), 603-609

López P and 5 others (2010) A regional view of fluctuations in glacier length in southern South America. Global Planet. Change, 71, 85-108 (doi: 10.1016/j.gloplacha.2009.12.009)

Machguth H, Eisen O, Paul F and Hoelzle M (2006a) Strong spatial variability of snow accumulation observed with helicopter-borne 
gpr on two adjacent alpine glaciers. Geophys. Res. Lett., 33(13), L13503 (doi: 10.1029/2006GL026576)

Machguth H, Paul F, Hoelzle M and Haeberli W (2006b) Distributed glacier mass-balance modelling as an important component of modern multi-level glacier monitoring. In MosleyThompson E and Thompson L, eds. Annals of glaciology, vol 43, 2006, volume 43 of annals of glaciology. International Symposium on High-Elevation Glaciers and Climate Records, Lanzhou, Peoples R China, SEP 05-09, 2005, 335-343 (doi: 10.3189/ 172756406781812285)

Masiokas MH and 5 others (2009) Glacier fluctuations in extratropical South America during the past 1000 years. Palaeogeogr. Palaeoclimatol. Palaeoecol., 281(3-4), 242-268 (doi: 10.1016/ j.palaeo.2009.08.006)

Oerlemans J (2001) Glaciers and climate change. A.A. Balkema Publishers, Lisse, Abingdon, Exton, Tokyo

Paul F, Escher-Vetter H and Machguth H (2009) Comparison of mass balances for Vernagtferner, Oetzal Alps, as obtained from direct measurements and distributed modeling. Ann. Glaciol., 50(50), 169-177 (doi: 10.3189/172756409787769582)

Rawson $\mathrm{H}$ and 6 others (2015) The frequency and magnitude of post-glacial explosive eruptions at volcán mocho-choshuenco, southern chile. J. Volcanol. Geotherm. Res., 299, 103-129 (doi: http://dx.doi.org/10.1016/j.jvolgeores.2015.04.003)

Rignot E, Rivera A and Casassa G (2003) Contribution of the Patagonia Icefields of South America to sea level rise. Science, 302(5644), 434-437 (doi: 10.1126/science.1087393)

Rivera A, Bown F, Casassa G, Acuna C and Clavero J (2005) Glacier shrinkage and negative mass balance in the Chilean Lake District $\left(40^{\circ} \mathrm{S}\right)$. Hydrol. Sci. J., 50(6), 963-974 (doi: 10.1623/hysj.2005.50.6.963)
Rosenblüth B, Casassa G and Fuenzalida H (1995) Recent climatic changes in western Patagonia. Bull. Glacier Res., 13, 127-132

Schaefer M, Machguth H, Falvey M and Casassa G (2013) Modeling past and future surface mass balance of the Northern Patagonian Icefield. J. Geophys. Res. Earth Surf., 118, 571-588 (doi: 10.1002/jgrf.20038)

Schaefer M, Machguth $H$, Falvey $M$, Casassa $G$ and Rignot $E$ (2015) Quantifying mass balance processes on the southern Patagonia icefield. Cryosphere, 9(1), 25-35 (doi: 10.5194/tc-925-2015)

Scheiter M (2016) Mass balance modeling on mocho glacier. Technical Report. Universidad Austral de Chile, Valdivia

Tachikawa T, Hato M, Kaku M and Iwasaki A (2011) Characteristics of aster gdem version 2. In Geoscience and remote sensing symposium (IGARSS), 2011 IEEE international, 3657-3660 (doi: 10.1109/IGARSS.2011.6050017)

Viale M and Garreaud R (2015) Orographic effects of the subtropical and extratropical andes on upwind precipitating clouds. J. Geophys. Res. Atmos., 120 (doi: 10.1002/2014JD023014)

Willis MJ, Melkonian K, Pritchard M and Ramage J (2012a) Ice loss rates at the Northern Patagonian Icefield derived using a decade of satellite remote sensing. Remote Sens. Environ., 117, 184-198 (doi: 10.1016/j.rse.2011.09.017)

Willis MJ, Melkonian K, Pritchard M and Rivera A (2012b) Ice loss from the Southern Patagonian Ice Field, South America, between 2000 and 2012. Geophys. Res. Lett., 39, L17501 (doi: 10.1029/2012GL053136)

Zemp M and 7 others (2015) Global glacier change bulletin no. 1 (2012-2013). Technical Report. ICSU(WDS)/IUGG(IACS)/ UNEP/UNESCO/WMO, World Glacier Monitoring Service, Zurich, Switzerland (doi: 10.5904/wgms-fog-2015-11)

MS received 6 June 2016 and accepted in revised form 7 November 2016; first published online 28 December 2016 